\title{
GCU
}

Glasgow Caledonian

University

University for the Common Good

\section{Ethnographies of social enterprise}

Mauksch, Stefanie; Dey, Pascal; Rowe, Mike; Teasdale, Simon

Published in:

Social Enterprise Journal

DOI:

10.1108/SEJ-03-2017-0019

Publication date:

2017

Document Version

Author accepted manuscript

Link to publication in ResearchOnline

Citation for published version (Harvard):

Mauksch, S, Dey, P, Rowe, M \& Teasdale, S 2017, 'Ethnographies of social enterprise', Social Enterprise Journal, vol. 13, no. 02, pp. 114-127. https://doi.org/10.1108/SEJ-03-2017-0019

\section{General rights}

Copyright and moral rights for the publications made accessible in the public portal are retained by the authors and/or other copyright owners and it is a condition of accessing publications that users recognise and abide by the legal requirements associated with these rights.

Take down policy

If you believe that this document breaches copyright please view our takedown policy at https://edshare.gcu.ac.uk/id/eprint/5179 for details of how to contact us. 


\title{
Ethnographies of social enterprise
}

\author{
Mauksch, S., Dey, P., Rowe, M., and Teasdale, S.
}

\begin{abstract}
Purpose: As a critical and intimate form of inquiry, ethnography remains close to lived realities and equips scholars with a unique methodological angle on social phenomena. This long editorial explores the potential gains from an increased use of ethnography in social enterprise studies.
\end{abstract}

Design/methodology/approach: We develop the argument through a set of dualistic themes, namely (1) the socio-economic dichotomy and (2) the discourse/practice divide as predominant critical lenses through which social enterprise is currently examined, and suggest shifts (3) from visible leaders to invisible collectives and (4) from case study-based monologues to dialogic ethnography.

Findings: We find that ethnography sheds new light on at least four neglected aspects. (1) Studying social enterprises ethnographically complicates simple reductions to socioeconomic tensions, by enriching the set of differences through which practitioners make sense of their work-world. (2) Ethnography provides a tool for unravelling how practitioners engage with discourse(s) of power, thus marking the concrete results of intervention (to some degree at least) as unplannable and yet effective (3) Ethnographic examples signal the merits of moving beyond leaders towards more collective representations and in-depth accounts of (self-)development. (4) Reflexive ethnographies demonstrate the heuristic value of accepting the self as an inevitable part of research and exemplify insights won through a thoroughly bodily and emotional commitment to sharing the life world of others.

Originality/value: The present volume collects original ethnographic research of social enterprises. The editorial develops the first consistent account of the merits of studying social enterprises ethnographically.

Keywords: ethnography; social enterprise; literature review

\section{Introduction}

As this special issue demonstrates, ethnography provides a clearer sense of the 'everydayness' of social enterprise, the paradoxical aspects of human practice and the subtle workings of power. It permits researchers to move beyond accounts which frame social enterprise as a pre-ordained, ready-to-use and thus decontextualized business 'model', 'approach' or 'hybrid'. Alternating from these typical classifications, we understand social enterprise as a social phenomenon that shapes, and is being shaped, through everyday practice. Echoing broader shifts towards accepting "life as a daily creative formation" (Steyaert and Katz 2004, 192), we understand social enterprise as performative enactment, i.e. as a kind of doing rather than a form of being. Such shift in attention to the ways in which social enterprise is performed as daily routine, demands an appropriate set of methods that remain close to the everyday. It follows that as ethnographers we are interested in the mundane experiences of social entrepreneurs and their interactions with a wider network of political actors, such as local and national government authorities, intermediaries and 
academics. Ethnography provides a sophisticated tool paying simultaneous attention to the complexity of everyday life and the wider political, cultural, social, spatial and temporal dimensions shaping social entrepreneurial practice.

Calls for ethnographic research into social enterprise are nearly as old as the field itself (Amin, Cameron, and Hudson 2008, Bull and Crompton 2006). But while many subdisciplines in Management and Organization Studies have been receptive towards ethnography over the last decade or so, there are few ethnographic studies of social enterprise. Somewhat disappointingly for an area of research that promised so much with regards to innovative methodological techniques and theoretical approaches (Haugh 2005), after an initial phase of anecdotal research (Lawrence, Phillips, and Tracey 2012), social enterprise researchers, with notable exceptions, have settled upon interview-based inquiries and qualitative, case-based explorative research designs (Sassmannshausen and Volkmann 2016). This led us, initially via a now annual seminar on social enterprise and ethnography, and now through this special issue, to discuss how ethnography might contribute something qualitatively different to existing social enterprise research; not simply as an additional methodological tool in the repertoire of how we deal with our subject of inquiry, but as an alternative way of conducting ourselves as researchers.

How does the work collected in this volume approach social enterprise? The study of a social enterprise hub in Denmark, by Eeva Houtbeckers, is organised around hyphen-spaces as mental maps structured by extreme points. Ethnography here emerges as a situational backand-forth between conflicting positions within a research setting, such as that of the aspiringly neutral observer vs. the emotionally engaged partner. Houtbeckers acquaints the reader with hope as a new hyphen-category, the coloration of which shifts from optimistic dreaming to anxieties of failure (and back) during the course of the study. Magdalena Zasada develops a comparative project that draws attention to substantial differences between social enterprises with shared objectives and a shared risk of closure. By zooming into the work of three health promotion organisations in the UK, Zasada shows that actors in the field negotiate pressures to entrepreneurialise through a diversity of impulses, ranging from entrepreneurial enthusiasm to organisational lethargy. Peter Wheeler realises his ethnography 'at home'. He re-engages with an organisation of and for people with disabilities whose radical edge he has co-established in the early years of "New Horizon". His narrative unravels a troubling case of compromised ideology and ongoing endeavours to re-establish radicalism despite institutional pressures towards conformity. Clementine O'Connor advocates a methodological innovation: the volunteer ethnographer. She suggests accepting ethnographic research in and with social enterprises as what it is: a form of collaboration. Volunteer ethnographers share the life-world of highly value-driven groups whose political ideals often accord well with the ethical premises of the researcher. Ethnographers are roped into the formal or informal role of a supporter who works side-byside with the people under study. This role is an ambivalent one in constant need of renegotiation, as $\mathrm{O}^{\prime}$ Connor shows. Kiri Langmead elaborates on her emotional vulnerability as a particularly productive angle on collective knowledge production. She develops insights into two organisations that position their democratic practices upfront and explores the meeting points of these lived ideals and her research performance. Langmead develops an opening closure of this issue. She provokes ethnographers to move beyond simply reflecting on the ways their engagement is shaped by biographical and personal history (such as demanded by writing culture), and towards accepting intersubjective knowledge-making as the mode through which the social world is enacted and reproduced. 
Of course, and as the diverse papers in this special issue demonstrate, 'ethnography' is a broad field hosting different intellectual influences. As this introductory article will necessarily remain selective, we have organised our argument along a series of thematic dualisms highlighted within the individual contributions to this special issue, and ethnographic research conducted by ourselves and others. These dualisms illustrate - with a pinch of hyperbole - the way in which social enterprise is usually studied. This enables us to show how ethnography adds to and twists perspectives on the respective phenomena. Of course, our approach to creating dualisms is problematic in itself. As we highlight in this special issue, ethnography has the potential to move beyond presumed dichotomies through breaking down the complexities of everyday social activity. We work with these dichotomies as aids to thinking, like crutches which come in pairs, while simultaneously denying them a state of catholicity or timelessness.

\section{Beyond Socio-Economic Antagonisms and towards Situated Enactment of Difference}

A common feature of existing social enterprise research is that it portrays hybridity, the tension-ridden relation between social mission and the financial goals, as a defining and stable characteristic of social enterprises (Doherty, Haugh, and Lyon 2014). At the core of social enterprises, these scholars assume, lie conflicting logics (Battilana and Dorado 2010), the dual mission of social purpose and financial sustainability (Dees and Elias 1998, Doherty, Haugh, and Lyon 2014), blended values (Nicholls 2009), or a double bottom line (Emerson and Twersky 1996). Research dealing with the hybridity of social enterprises initially seems to transcend the grand narratives of social enterprise (Dey and Steyaert 2010) - that is, epochalist accounts that claim universal validity and practical utility - by focusing on their lived reality. However, closer inspection reveals that much of this research is predicated on an essentialism that suggests that tensions and hybridity define what social enterprise is rather than being an academic way of framing social enterprise. Accepting that social enterprises are essentially about negotiating conflicting aims involves two bold presumptions. First, it assumes that the social-economic dichotomy is an endemic quality of social enterprises. This risks rendering social enterprise as a sui generis entity (Latour 2005), that is, an entity 'of its own kind'. However, decision-makers in most forms of organisations (such as bureaucracies, adhocracies or ordinary non-profits) similarly need to balance business, social and ecological demands (Hillman and Keim 2001). Second, the motif of tension ignores the ethics and sociality of economics itself (Polanyi 1957). Treating the 'social' and 'economic' as two separate entities, each with its distinct and stable core, and imagining them as antagonistically related (a tension, a contrast, or a continuum), encourages us to treat social enterprises as stable and uniform, and dissuades us from embracing their processes, complexities and differences.

Ethnography allows us to accept the complexity of social activity while refuting tendencies towards essentialism. Indeed, ethnography might support us in understanding that the hybridity of social enterprise is less a thing than an on-going enactment and (re)negotiation of differences that proceeds without an assumed hierarchy or binary opposition between the 'social' and 'economic'. Furthermore, ethnography cautions that we should not reduce the domain of social enterprise to a dualistic logic since social enterprise comprises the complex interweaving of myriad 'logics'. In this way, ethnography has the potential to demonstrate that practitioners in the field are perfectly aware that the mundane reality of social enterprise does not pertain to strict boundaries. Rather, social enterprise comprises the intermingling of 
contradictory, opposing views and practices as practitioners within their talk and action constantly move back and forth along the avowed opposition between the social and the economic, the individual versus the collective, the professional versus the anarchic, the public face versus the private face... and so on (Dey and Teasdale 2016). They thus operate in a field of oscillating difference where diverse 'logics' perpetually cross over without any view ever gaining the (permanent) upper hand. We refrain from saying that tensions are not a useful way of making sense of social enterprise here, simply that they are insufficient to explain social enterprise. As this special issue shows, the tensions faced by social enterprise practitioners in their everyday lives are myriad, interconnected, and must be constantly renegotiated.

Houtbeckers (this volume) develops a new take on the tension theme, one that admits the researcher into the picture. The constant struggle of members of a social hub in Copenhagen, between "working out of love" and "working for money", mirrors the author's emphatic commitment to the organisation. The researcher moves back-and-forth between sharing spirit and rationalising on occurrences, including more pragmatic decisions around involvement. Her understanding deepened while journeying between poles of producing $\mathrm{PhD}$ research and the pragmatics of supporting the organisation (emotionally, financially) in precarious times. Such uncertainties are at stake in Zasada's (this volume) contribution, too. The stories of two out of three organisations reconfirm earlier insights that "climate[s] of expectation" in social enterprises can easily lead to burn-out and unexpected closure with disheartening effects for vulnerable users (Froggett and Chamberlayne 2004, 72). Some of the members in Zasada's study concluded that they want to, but 'lack time' to entrepreneurialise. This statement produces an irony, given the general framing of entrepreneurial organisation as the reverse of time and resource-intense 'bureaucracy' (du Gay 2004). Tension here is not only inherent to the organisation's everyday routines, but also emerges from discrepancies between these current modes of work and efforts to invest in future-oriented aspirations. The third of Zasada's cases sets an interesting counterpoint, because tension here is consciously avoided. The $60+$ volunteers in charge of running organisational affairs proactively decide to stay out of business activities, even at the risk of failure. Voluntary engagement should not "feel like job".

Wheeler (this volume) puts forward a procedural understanding of 'tension' that traces the development of a radical organisation under institutional pressures. New Horizon used to be run largely by and for people with disabilities and was underpinned by strong ideological claims. Its radical aspects were subject to constant renegotiation, but clearly positioned against the well-meaning, yet damaging paternalism of NGOs in the field. While NGOs did repair work, early managers of New Horizon sought to deconstruct the concept of disability altogether. Their questions were paramount: How can we speak on behalf of ourselves? How do we achieve equal participation of differently-abled people? New Horizon's story depicts the struggle for sustaining a radical philosophy in an 'entrepreneurialising' institutional environment. It diverts from the usual double-bind of sustaining morally and economically as a social enterprise. Because New Horizon's target subjects and implementers form one group, adopting entrepreneurial logics (that build on individuals' market potential) - deeply compromised their identity. Once the organisation accepted a rationale that categorises people with disabilities as 'difficult to place' in employment markets, it began seeing people with disabilities as lacking something; and shifted practice towards assessing and developing them with reference to their employability and economic contribution to society. These, of course, were governmental objectives rather than those set by their clients. Wheeler 
hints at social enterprise's tendency to depoliticise the root causes of inequality (Eikenberry and Kluver 2004) and to jeopardise the non-profit sector's task of critiquing societal conditions (Dempsey and Sanders 2010).

These contributions demonstrate the merits of shifting perspective from a view on tension and hybridity as stable essences to the more procedural themes of (tension-laden) survival and uncertainty. While New Horizon failed to survive as a radical organisation, the Danish hub strove for sustaining optimism among organisational members. Zasada traces tactics of survival in three divergent organisations. One sustains through expanding market activity, the second through recurrent postponing of entrepreneurialisation, and the third through keeping up the routine volunteer work - associated with informality and a nonprofessionalised image in the community. Tracing subjects' tactics of survival adds an important temporal and processual perspective to extant research, particularly that dealing with spatial aspects - how performances in one space might be tactical manoeuvres designed to create freedom for action in other (less visible) spaces (Dey and Teasdale 2016). It creates the opportunity to engage, inductively, with all kinds of tensions in organisational practices as they evolve, rather than presuming an essential, preordained dilemma. The tensions theme, in other words, comes with its own merits, but may blind us to other issues at stake in social enterprises' organisational realities.

\section{From Discourse-Practice to Discourse/Practice}

(Critical) scholars have endeavoured to deconstruct normalised assumptions and to scrutinise taken-for-granted claims pertaining to social enterprise as a (more) effective approach to social problem solving (see Special Issue "Critical Perspectives on Social Enterprise" in this journal; 2012, Vol. 8 Iss: 2) or around the rise of social enterprises being a quasi-spontaneous reaction to market and state failure (Teasdale, Lyon, and Baldock 2013). Discursive research has proven particularly helpful in illuminating how powerful actors use language as a way of normalising specific views and realities of social enterprise. Teasdale and colleagues for one show that English policy makers defined social enterprise as vaguely as possible in order to integrate a large array of organisational types (Teasdale 2012b). In turn, this enables government statisticians to loosely interpret their own surveys to 'demonstrate' dramatic growth in social enterprises in England since 2003 (Teasdale 2012b, Teasdale, Lyon, and Baldock 2013). Nicholls (2010) and Mason (2012) trace the legitimating strategies of (again English) paradigm builders, while others reveal that academia is complicit in producing and reproducing the ideal imagery promoted by policy makers (Dey and Steyaert 2010, Steyaert and Dey 2010). These examples epitomize critical research's affinity with discursive research, and show how this alliance has demonstrated how 'words' not only present social enterprise in different ways but 'create', ontologically speaking, the very thing they apparently only represent.

Our understanding of language's constitutive power takes on an entirely different coloration if we include ethnographic research scrutinising how prevailing discourses of social enterprise are dealt with at the level of practice. A consistent thread that runs through ethnographic research is that there is a notorious gap between dominant discourses of social enterprise (advanced by academics, policy makers, incubators, etc.) and the way in which these discourses are appropriated and reproduced in practice. A relatively unnoticed, but 
potentially fertile, stream of research traces how social enterprise practitioners struggle against, oppose or divert from dominant governmental discourses (Parkinson and Howorth 2008, Seanor et al. 2014). Wheeler's and Zasada's articles shed light on the effects of this pressure to entrepreneurialise, albeit with differing results and interpretations. They show how English policy makers operate not just on the mental level of conviction, but reinforce their program through policies and funding mechanisms reshaping the third sector in a more professional image. While previously grants were used to fund organisations and programmes, this changed under New Labour to contract-based funding targeted at specific outcomes. This move towards quantifying the efficacy of social and welfare work shook the fundaments of these organisations. New Horizon, for instance, momentarily shifted from an approach involving employing unskilled people and training them, and towards employing professionals who act as trainers for clients. Such employment patterns fitted the local authority's focus on hard outcomes of independent living programs, for which trainers had to be properly qualified. In this case, New Horizon terminated the partnership after facing its ideologically damaging effects, but there are many other adaptations classified by Wheeler as a "giving in" or "tempering" of radicalism.

Beyond offering such nuanced accounts of how normative pressures are negotiated at the level of practice, ethnography also contributes to what one may call a 'post-heroic turn' in social enterprise studies. Drawing from its potential to map the naturalisation of discourse (Comaroff 2010) and its testimony of lived and living practice (Bourdieu 1977, Geertz 1973), ethnography has enriched critical epistemologies of social enterprise. Early examples undermine heroic renditions by depicting the social economy as "pretty unglamorous, sometimes slow or without future promise" (Amin 2009, 31), which is at odds with the 'enchanted' realms in which social enterprise is advertised (Mauksch 2016). The everyday life of a social entrepreneur turns out to be less spectacular (Amin 2009), less heroic (Parkinson and Howorth 2008), less harmonious, and more complex and dilemmatic (Berglund and Schwartz 2013) than proposed in dominant imageries. Persons active in the field have incorporated modes of travelling between these worlds and tactically mimic social entrepreneurship's positive language (Dey and Teasdale 2016). Scholars unsettled the field's optimism by showing that social enterprise fails to hold on to its promise of inclusiveness for people suffering serious or multiple deprivation (Amin, Cameron, and Hudson 2008). The pressures of conforming to financial environments dictated by government funding mechanisms, and of competing with 'efficient' (read 'low paying') businesses in similar fields means that many social enterprises are unable to serve the most disadvantaged groups, for example homeless people facing addiction, unemployment, and broken family relations (Dart 2004, Teasdale 2012a). Those social enterprises that reach maturity tend towards managerial pragmatism, "with ethical values hovering somewhere in the background" (Amin 2009, 40).

Yet ethnographers of social enterprise need not limit themselves to contrasting discourse with practice, or to understanding how practitioners identify/disidentify with discourse. Ethnography can enable the movement beyond, or at least further complication of, the theory-practice or macro-micro distinction. Opportunities arise from pinpointing the micro in the macro - the everyday worlds of leaders in the field (Mauksch 2016) - or the macro in the micro - the ways by which individual subjects reproduce discourse even in their most 
intimate registers (Dey 2014, Mauksch in press). In Mauksch's (2016) study, for example, a participant in a global campaigning event claims that social business (enterprise) is "exactly what it was in [her] ... with a new word on it". The quote shows how social enterprise discourse does not simply impose itself on people, but powerfully constitutes new modes of being. Social enterprise is here presented as a category prior to its own figuration, as something that is 'within' people in a very intimate and personal sense.

An interesting new leading edge for ethnography is to spotlight what social enterprise discourse actually achieves, with a more positive connotation. In the spirit of Ferguson's (2010) "The Uses of Neoliberalism", one has to acknowledge not only entrepreneurship's potential to 'colonise' certain perspectives (Tedmanson et al. 2012), but also the unintended effects social enterprise produces in almost accidental ways. Ethnographic research, we believe, puts an opportunity in front of us to heed the role of happenstance, 'dumb luck' and unplanned outcomes, which are conspicuously absent in rationalistic management accounts, as central components in the life of social enterprises. For example, a recent study by Dey (2016) redirects attention to the practical effects of entrepreneurship in moments of societal crisis. Based on the Argentine experience in 2001 where unemployed workers reclaimed their abandoned factories to resume production, Dey's investigation shows how entrepreneurship in particular situations functions as an 'engine' for increasing the resilience of entire communities. Entrepreneurial creation implicates acts of subversion that eventually reshape society in positive ways. In this spirit, Houtbeckers (this volume) indicates that the failure of a hub in Copenhagen, which was also a personal and economic failure for some, still influenced individuals' lives in ways that they personally appreciated, including the author herself. The hub had institutionalised an ethos of hope in Miyazaki's (2006) sense of a forward-looking spirit in an apparently hopeless situation. The creation of a motivational, interpersonal space that sustained its vibrancy even after the hub had ceased to exist is one of the 'accidental' achievements of social enterprise that the author asks us to appreciate.

\section{From Individual Leaders' Accounts to Collective Representations}

Another key contribution ethnography can make is to provide the means for counter-acting the 'great men' theory of social enterprise, which was particularly influential in early academic debates (Spear 2006). Indeed, the managing side of social enterprise is well explored. Ethnographic research and in-depth interviewing have shown that social enterprises often rely on the "ingenuity, contacts and sheer hard work of dedicated individuals" (Amin 2009, 35). These managers (and usually founders) tend to adopt an alarming approach to work-life balance issues- with the emphasis on the first part of the hyphen. Social entrepreneurs, so it seems, fail to personally adhere to the standards of ethical work they aspire to for others (Dempsey and Sanders 2010) and risk not only financial loss, but their personal credibility and reputation (Shaw and Carter 2007). These are framed as "costs of meaningful work" (Dempsey and Sanders 2010, 439, see also Mauksch 2016). Employees lower down the hierarchy instead "value the possibility of staying out of the faster, more pressurised, less tolerant economic mainstream" (Amin 2009, 44). Alternative entrepreneurial characters beyond the archetypical "white, male entrepreneur" (Tedmanson et al. 2012) have entered the setting. Berglund and Schwartz (2013) 'shadowed' Swedish social entrepreneur Sandhya Randberg, a women adopted from India as a child who 
commits herself to changing the life conditions in her country of birth. The story illustrates the need to biographically contextualise the social entrepreneur's narration and the merits of moving beyond opportunity recognition as a motivation to venture for the social good. Voicing nurse Nell through biographical narrative, Froggett and Chamberlayne (2004) enunciate that heroic figures (persons who have 'advanced' from a state of marginality and deprivation) frame their personal developments differently from public rhetorics. Nell's account speaks of silence, suffering, passivity and decisions that were made for her. Her narration puts in question the highly self-aware image of ideal entrepreneurs who shape their life through proactive decisions.

Emerging from the field of (postcolonial) Anthropology, ethnography operates as an instrument of cultural critique (Marcus and Fischer 1999) that privileges the social realms of colonized, deprived and marginalized groups of people. The desire is to disrupt dominant male and Western representations by "giving voice" to those unheard, while admitting the limitations of such operation (Beverley 1999). Social enterprise scholars frequently note the absence of target subjects' voices from research accounts (e.g. Amin 2009, Mauksch 2016). This absence is suspicious given the agenda to effectuate "a return of the 'fallen' into the formal economy" (Amin 2009, 34) and creational myths of "saving the world" (Sørensen 2008). The fact that only one of the submissions to this special issue (O'Connor's) concentrates on the realities of beneficiaries mirrors organisation studies' historically grown focus on managers rather than those whose role is to be 'managed'. Nevertheless, the interest in mundanity taken by authors in this special issue evokes a shift from "the view of an elitist group of entrepreneurs" (Steyaert and Katz 2004, 192) towards more encompassing representations that embed social enterprises within a community (Mauksch and Rowe 2016). These accounts hint at the importance of the social environment of social enterprise as the context evident for a "thick description" (Geertz 1973).

O'Connor's contribution (this volume) creates this sense of sharing the life-world of a vulnerable community. The author experienced one of the eye-opening moments of an ethnographer who is overwhelmed by how deeply engaged she has become. The self-reliant group she was working with turned into a space of relief from her everyday pressures, just as it had for the other women. This moment served as a lens into the lives of women for whom the home had become an uncomfortable place housing the "difficult bits of their lives". O'Connor is well aware of her privileged position and the degree to which her experiences are bound to a field experience - a field that she will leave while others stay. Yet the reader gets a sense of why the women uphold their activities in the group and of the deeper meanings they attribute to it. Overton Wellbeing Group, the third community health organisation introduced by Zasada, is kept alive by the voluntary commitment of elderly people who themselves face health problems. The commonality between these two collectives - the self-reliant groups in O'Connor's work and the elderly volunteers in Zasada's - is that they find new meaning in supporting other people perceived as more vulnerable than themselves. This insight complicates the boundaries between givers and takers of social entrepreneurial commitment. Social enterprise here again evolves as a relational space beyond organisational type, a fluctuating network of entangled persons.

A further opportunity for collective representations are so-called multi-sited ethnographies which are not restricted to one observational site (such as a single organization), but which pay apt heed to the spatial - i.e. local, national, and transnational - dynamics of social enterprises (Marcus 1995). Multi-sited ethnographies are hence particularly relevant to 
exploring social enterprise as a 'fuzzy' phenomenon (Nadai and Maeder 2005) which defies clear (organisational) boundaries. Consider types of social enterprise activities whose agency cannot be located in a single organisation but which involves an entire web of actors. For example, one might seek to explore the co-creation of social enterprise 'strategies' by policy and social enterprise actors. A multi-sited ethnography would imply starting with relevant actors and their interaction with the (processes) of co-creation, exploring the ways in which differently positioned actors relate to and engage with each other. Unlike ethnographies which study cultural practices in a relatively limited geographical realm (e.g. an office or a village), multi-sited ethnographies suggest that researchers participate in patterns of movement to become part of the powerful performativity of flows of bodies, stories, images, and objects. Researchers are thus co-present in the respective movements and apply a range of interviewing, observing, and recording technologies 'on the move' (Büscher, Urry, and Witchger 2010) .

\section{From Research as Monologue to Research as Dialogue and Participation}

Another window this volume seeks to open is related to methodology. Three out of five contributions claim that social enterprise research lacks reflexivity, although the usual exceptions - such as Froggett and Chamberlayne (2004) - do exist. In the latter, a simultaneous laughter in the interview is understood as a shared perception of Nell's passivity and her ironic self-deprecation. In a similar mode, authors in this volume direct the reader's attention to the dynamic reflexivity of the interpretive process, thus diverting from the methodological techniques usually employed in social enterprise research. These are, as widely stated in reviews and a bibliometric analysis published in this journal, primarily case studies and/or interview-based studies (Granados et al. 2011), focusing on the nature or role of social entrepreneurs (Dacin, Dacin, and Tracey 2011), their networks and typology (Phillips et al. 2015). Even though the field has become more diverse recently (Sassmannshausen and Volkmann 2016), it is lacking the kind of reflexive and/or dialogical experiments produced in the wider field of Organisation Studies (e.g. Ford and Harding 2008, Steyaert 2011, Steyaert and Landström 2011).

Houtbeckers (this volume) argues that the researching self should be accepted as part of the research. She draws these ideas from Fine's (1994) notion of the hyphen - a concept that traces the simultaneously linked and divided relational positioning of the researcher vis-àvis 'respondents' (see also Cunliffe and Karunanayake 2013). Recalling the hyphens at work in her field site, Houtbeckers explores the intersubjective nature of knowing through ethnography and the ways her research exposed herself to vulnerability. Langmead's (this volume) partners found it difficult to 'teach' incomers the values of the organisation. Instead, one should learn while doing it - and so should the researcher. Democratic practices in the two organisations studied were not made explicit or rhetorically framed, but lived and enacted as a daily routine. Langmead's is an account that appreciates knowledge as practice and takes her learning as an object of study. For instance, whereas organisation 1 negotiated the question whether 'to let a researcher in' through the very participatory modes that shape their other activities, organisation 2 was much less consistent in living what it preached. When quoting Fran and Lisa, who remind themselves that their statements might "go into the little book" (the field jottings) and jokingly consider themselves as "jealous of her important work", Langmead openly and self-ironically engages with the effects of her presence. She moves beyond showing how positionality informs the type of knowledge that 
is produced, instead harvesting from the creative moments that reshaped understanding on both the researching and researched side (Mauksch and Rao 2014).

Methodologies are accepted as more than just tools, but rather as forms of intervening vis-àvis societal or community issues, thus highlighting the performative and participative dimension of every research practice (Steyaert 2011, Steyaert and Katz 2004). O'Connor (this volume) is particularly attentive to this notion. She questions whether in the field of social enterprise the 'volunteer ethnographer' might not be an exception but the norm. She refers to social enterprises as organisations in which one cannot remain outside, but which expect commitment and attribute a co-constructive role even to the critical outsider. O'Connor plots some of the complexities and unease produced by this hyphened role and asks whether the boundary shifting is similar in kind to the dilemmas research subjects face. The feeling of being drawn into responsibility is shared by Houtbeckers (this volume), who ends up being a contributing hub member. Langmead (this volume) instead faced difficult decisions around which slices of reality are important for her to share. Like O'Connor, Langmead is haunted by the fear of missing crucial moments by virtue of being elsewhere. All three narrations establish insight into new fieldwork settings in which the researcher's co-working role may compromise her epistemological interest. They recall ethnographers' well-known struggle around how to give back in the field while at the same time opening new horizons. In professionalised settings, the researcher is no longer the foreigner suspiciously interested in 'our culture', but an academic who shares interest in the kind of knowledge that research subjects themselves are interested in and whose presence must be defended (Mauksch and Rao 2014).

\section{The Merits of Ethnography}

The argument of this overview article has been that research on social enterprise can benefit considerably if we grant ethnographic approaches a proper place in our research agenda. From this necessarily brief overview of ethnographic literature on social enterprise, we would conclude that: (1) Studying social enterprises ethnographically complicates simple reductions to socio-economic tensions, by enriching the set of differences through which practitioners make sense of their work-world. (2) Ethnography provides a tool for unravelling how practitioners engage with discourse(s) of power, thus marking the concrete results of intervention (to some degree at least) as unplannable and yet effective. (3) Ethnographic examples signal the merits of moving beyond leaders towards more collective representations and in-depth accounts of (self-)development. (4) Reflexive ethnographies demonstrate the heuristic value of accepting the self as inevitably part of research and exemplify insights won through a thoroughly bodily and emotional commitment to sharing the life-world of others.

We are well aware of the perceived obstacles of a time-consuming research practice that is usually in review processes of academic journals - painfully measured against precisely those values of positive science (validity, rigour, reliability and the like) which ethnographic epistemologies seek to question. These practical caveats notwithstanding, young scholars may find relief in powerful arguments against the making-fit of ethnography to principles defined on a very different epistemological basis - one that seeks reproducible laws and generally applicable theories (see, for example, Schwartz-Shea 2006, Van Maanen 2011, Stanley 1990, for a critical reflection). Rather than following a defensive track that predicts a 
positivist critique and aspires for 'rigorous' ethnographic accounts (e.g. Watson 2011), we prefer here to recall more actively the unique strengths of ethnography.

First, ethnography critically estranges the lived world. It questions the processes by which something we perceive as a given has reached this stage of normality, thus reminding readers that the phenomenon at hand is a product of human practice rather than a given 'concept'. Social enterprises should thus be studied as entities in the making, reproduced through usually uncommented upon, mundane activities that need to be named, made explicit, carved out and co-interpreted. Second, ethnography is an apt methodology to accept at least some of the complexity, paradoxes and complications of social reality, by strategically refraining from deterministic and simplified representations. This strategy necessitates walking a difficult tightrope between creating accessible and discrete accounts of social reality, while revealing loose ends and constantly reminding audiences of the existence of alternative subjective realities. To some degree, ethnography intentionally denies readers the satisfaction produced by authoritative and definitive truth-claims about how things 'actually are' by retaining portions of the fuzziness of human experience. Third, ethnography starts at the beginning rather than the end of theorising and seeks to establish 'midrange theories' that sustain proximity to the life-worlds of those under study. Social enterprise here emerges as whatever it is for the people who enact it as a daily routine: a form, a philosophy, a self-ascription, a hope, or a label. From this vanguard, more abstract understandings evolve that pose social enterprise as a discourse, a network, a mode of being or a structured practice. Fundamental to ethnographers, in developing a theory that is 'grounded' in the everyday, are the continuous, abductive shifts between an insider's self-understanding and an outsider's analytical abstraction. Fourth, ethnography appreciates context in ways no other method does. Fragments of fieldwork accounts stand in for a much broader picture of reality - a reality that needs to be intimately shared and known in order to make sense of the individual experience, statement or observed activity. The socialisation of the researcher into a particular life-world allows her to draw from her own experiences to render endemic concepts explicable to readers unfamiliar with the respective setting, without however claiming to create a transparent account of 'their' realities in any point of time. This leads us to our fifth and final point: ethnographic endeavours strive not just for reflexivity on the positionality of the researcher, but also accept the co-production of reality. The process of knowledge-making is itself something ethnographers critically reflect on, accepting the nonlinearity and fluidity of experience as a given. In providing these five points of (self) assurance for ethnographers of social enterprise, we hope to spark ethnographic experiments in the field social enterprise and a wider level of acceptance for a promising methodology.

Amin, Ash. 2009. "Extraordinarily Ordinary: Working in the Social Economy." Social Enterprise Journal 5 (1):30-49.

Amin, Ash, Angus Cameron, and Ray Hudson. 2008. Ethnographies of the Social Economy: Practices in Place. In Non-Technical Summary (Research summary) ESRC End of Award Report, RES-000-23-0987. Swindon: ESRC.

Battilana, Julie, and Silvia Dorado. 2010. "Building Sustainable Hybrid Organizations: The Case of Commercial Microfinance Organizations." Academy of Management Journal 53 (6):1419-1440. 
Berglund, Karin, and Birgitta Schwartz. 2013. "Holding on to the Anomaly of Social Entrepreneurship Dilemmas in Starting up and Running a Fair-Trade Enterprise." Journal of Social Entrepreneurship 4 (3):237-255.

Beverley, John. 1999. Subalternity and Representation: Arguments in Cultural Theory. Durham: Duke University Press.

Bourdieu, Pierre. 1977. Outline of a Theory of Practice. Cambridge: Cambridge University Press.

Bull, Mike, and Helen Crompton. 2006. "Business Practices in Social Enterprises." Social Enterprise Journal 2 (1):42-60.

Büscher, Monika, John Urry, and Katian Witchger. 2010. Mobile Methods. New York: Routledge.

Comaroff, John. 2010. "The End of Anthropology, Again: On the Future of an in/Discipline." American Anthropologist 112 (4):524-538.

Cunliffe, Ann L, and Geetha Karunanayake. 2013. "Working within Hyphen-Spaces in Ethnographic Research Implications for Research Identities and Practice." Organizational Research Methods 16 (3):364-392.

Dacin, M Tina, Peter A Dacin, and Paul Tracey. 2011. "Social Entrepreneurship: A Critique and Future Directions." Organization Science 22 (5):1203-1213.

Dart, Raymond. 2004. "Being "Business-Like" in a Nonprofit Organization: A Grounded and Inductive Typology." Nonprofit and Voluntary Sector Quarterly 33 (2):290-310.

Dees, J Gregory, and Jaan Elias. 1998. "The Challenges of Combining Social and Commercial Enterprise. University-Business Partnerships: An Assessment." Business Ethics Quarterly 8 (01):165-178.

Dempsey, Sarah E, and Matthew L Sanders. 2010. "Meaningful Work? Nonprofit Marketization and Work/Life Imbalance in Popular Autobiographies of Social Entrepreneurship." Organization 17 (4):437-459.

Dey, Pascal. 2014. "Governing the Social through 'Social Entrepreneurship': A Foucauldian View of 'the Art of Governing'in Advanced Liberalism." In Social Entrepreneurship and Enterprise: Concepts in Context, edited by Heather Douglas and Suzanne Grant, 55-72. Melbourne: Tilde University Press.

Dey, Pascal. 2016. "Destituent Entrepreneurship: Disobeying Sovereign Rule, Prefiguring Post-Capitalist Reality." Entrepreneurship \& Regional Development 28 (7-8):563-579.

Dey, Pascal, and Chris Steyaert. 2010. "The Politics of Narrating Social Entrepreneurship." Journal of Enterprising Communities: People and Places in the Global Economy 4 (1):85-108.

Dey, Pascal, and Simon Teasdale. 2016. "The Tactical Mimicry of Social Enterprise Strategies: Acting 'as If' in the Everyday Life of Third Sector Organizations." Organization 23 (4):485-504.

Doherty, Bob, Helen Haugh, and Fergus Lyon. 2014. "Social Enterprises as Hybrid Organizations: A Review and Research Agenda." International Journal of Management Reviews 16 (4):417-436.

du Gay, Paul. 2004. "Against 'Enterprise' (but Not against 'Enterprise', for That Would Make No Sense)." Organization 11 (1):37-57.

Eikenberry, Angela M, and Jodie Drapal Kluver. 2004. "The Marketization of the Nonprofit Sector: Civil Society at Risk?" Public Administration Review 64 (2):132-140.

Emerson, Jed, and Fay Twersky. 1996. New Social Entrepreneurs: The Success, Challenge and Lessons of Non-Profit Enterprise Creation. San Francisco: Rhe Roberts Foundation.

Ferguson, James. 2010. "The Uses of Neoliberalism." Antipode 41 (s1):166-184.

Fine, Michelle. 1994. "Working the Hyphens." In Handbook of Qualitative Research, 70-82. Thousand Oaks: Sage.

Ford, Jackie, and Nancy Harding. 2008. "Fear and Loathing in Harrogate, or a Study of a Conference." Organization 15 (2):233-250. 
Froggett, Lynn, and Prue Chamberlayne. 2004. "Narratives of Social Enterprise from Biography to Practice and Policy Critique." Qualitative Social Work 3 (1):61-77.

Geertz, Clifford. 1973. The Interpretation of Cultures: Selected Essays. New York: Basic books.

Granados, Maria L, Vlatka Hlupic, Elayne Coakes, and Souad Mohamed. 2011. "Social Enterprise and Social Entrepreneurship Research and Theory: A Bibliometric Analysis from 1991 to 2010." Social Enterprise Journal 7 (3):198-218.

Haugh, Helen. 2005. "A Research Agenda for Social Entrepreneurship." Social Enterprise Journal 1 (1):1-12.

Hillman, Amy J, and Gerald D Keim. 2001. "Shareholder Value, Stakeholder Management, and Social Issues: What's the Bottom Line?" Strategic Management Journal 22 (2):125139.

Houtbeckers, Eeva. 2017. "Researcher Subjectivity in Social Entrepreneurship Ethnographies: The Entanglement of Stories in a Co-Working Cooperative for Social Innovation." Social Enterprise Journal 13 (2).

Langmead, Kiri. 2017. "From Cooperative Practice to Research and Back: Learning from the Emotional Experience of Ethnography." Social Enterprise Journal 13 (2).

Latour, Bruno. 2005. Reassembling the Social: An Introduction to Actor-Network-Theory. London: Oxford University Press.

Lawrence, Thomas, Nelson Phillips, and Paul Tracey. 2012. "From the Guest Editors: Educating Social Entrepreneurs and Social Innovators." Academy of Management Learning E Education 11 (3):319-323.

Marcus, George E. 1995. "Ethnography in/ of the World System: The Emergence of MultiSited Ethnography." Annual Review of Anthropology 24 (1):95-117.

Marcus, George E, and Michael MJ Fischer. 1999. Anthropology as Cultural Critique: An Experimental Moment in the Human Sciences. Chicago: University of Chicago Press.

Mason, Chris. 2012. "Up for Grabs: A Critical Discourse Analysis of Social Entrepreneurship Discourse in the United Kingdom." Social Enterprise Journal 8 (2):123-140.

Mauksch, Stefanie. 2016. "Managing the Dance of Enchantment: An Ethnography of Social Entrepreneurship Events." Organization. doi: 10.1177/1350508416644511.

Mauksch, Stefanie. in press. "It Is Exactly What It Was in Me': The Performativity of Social Entrepreneurship." In Critical Perspectives on Social Entrepreneurship, edited by Pascal Dey and Chris Steyaert. Cheltenham: Edward Elgar.

Mauksch, Stefanie, and Ursula Rao. 2014. "Fieldwork as Dialogue. Reflections on Alternative Forms of Engagement." Zeitschrift für Ethnologie 139 (1):23.

Mauksch, Stefanie, and Mike Rowe. 2016. "Austerity and Social Entrepreneurship in the United Kingdom: A Community Perspective." In New Perspectives on Research, Policy $\mathcal{E}$ Practice in Public Entrepreneurship (Contemporary Issues in Entrepreneurship Research, Volume 6), edited by Joyce Liddle, 173-193. London: Routledge.

Miyazaki, Hirokazu. 2006. The Method of Hope: Anthropology, Philosophy, and Fijian Knowledge. Stanford: Stanford University Press.

Nadai, Eva, and Christoph Maeder. 2005. "Fuzzy Fields. Multi-Sited Ethnography in Sociological Research." Forum Qualitative Sozialforschung/Forum: Qualitative Social Research.

Nicholls, Alex. 2009. "'We Do Good Things, Don't We?': 'Blended Value Accounting' in Social Entrepreneurship." Accounting, Organizations and Society 34 (6):755-769.

Nicholls, Alex. 2010. "The Legitimacy of Social Entrepreneurship: Reflexive Isomorphism in a Pre-Paradigmatic Field." Entrepreneurship Theory and Practice 34 (4):611-633.

O'Connor, Clementine. 2017. "Working with and for Social Enterprises: The Role of the Volunteer Ethnographer." Social Enterprise Journal 13 (2).

Parkinson, Caroline, and Carole Howorth. 2008. "The Language of Social Entrepreneurs." Entrepreneurship and Regional Development 20 (3):285-309. 
Phillips, Wendy, Hazel Lee, Abby Ghobadian, Nicholas O’Regan, and Peter James. 2015. "Social Innovation and Social Entrepreneurship a Systematic Review." Group $\mathcal{E}$ Organization Management 40 (3):428-461.

Polanyi, Karl. 1957. The Great Transformation: The Political and Economic Origin of Our Time. Boston: Beacon Press.

Sassmannshausen, Sean Patrick, and Christine Volkmann. 2016. "The Scientometrics of Social Entrepreneurship and Its Establishment as an Academic Field." Journal of Small Business Management.

Schwartz-Shea, Peregrine. 2006. "Judging Quality: Evaluative Criteria and Epistemic Communities." In Interpretation and Method. Empirical Research Methods and the Interpretive Turn, edited by Dvora Yanow and Peregrine Schwartz-Shea, 89-114. Armonk, New York: M.E. Sharpe.

Seanor, Pam, Michael Bull, Susan Baines, and Martin Purcell. 2014. "Where Social Enterprise Practitioners Draw the Line: Towards an Understanding of Movement from Social Entrepreneurship as Boundary Work." International Journal of Public Sector Management 27 (4):353-368.

Shaw, Eleanor, and Sara Carter. 2007. "Social Entrepreneurship: Theoretical Antecedents and Empirical Analysis of Entrepreneurial Processes and Outcomes." Journal of Small Business and Enterprise Development 14 (3):418-434.

Sørensen, Bent Meier. 2008. "'Behold, I Am Making All Things New': The Entrepreneur as Savior in the Age of Creativity." Scandinavian Journal of Management 24 (2):85-93.

Spear, Roger. 2006. "Social Entrepreneurship: A Different Model?" International Journal of Social Economics 33 (5/6):399-410. doi: doi:10.1108/03068290610660670.

Stanley, Liz. 1990. "Doing Ethnography, Writing Ethnography: A Comment on Hammersley." Sociology 24 (4):617-627. doi: 10.1177/0038038590024004004.

Steyaert, Chris. 2011. "Entrepreneurship as in (Ter) Vention: Reconsidering the Conceptual Politics of Method in Entrepreneurship Studies." Entrepreneurship and Regional Development 23 (1-2):77-88.

Steyaert, Chris, and Pascal Dey. 2010. "Nine Verbs to Keep the Social Entrepreneurship Research Agenda 'Dangerous'." Journal of Social Entrepreneurship 1 (2):231-254.

Steyaert, Chris, and Jerome Katz. 2004. "Reclaiming the Space of Entrepreneurship in Society: Geographical, Discursive and Social Dimensions." Entrepreneurship \& Regional Development 16 (3):179-196.

Steyaert, Chris, and Hans Landström. 2011. "Enacting Entrepreneurship Research in a Pioneering, Provocative and Participative Way: On the Work of Bengt Johannisson." Small Business Economics 36 (2):123-134.

Teasdale, Simon. 2012a. "Negotiating Tensions: How Do Social Enterprises in the Homelessness Field Balance Social and Commercial Considerations?" Housing Studies 27 (4):514-532.

Teasdale, Simon. 2012b. "What's in a Name? Making Sense of Social Enterprise Discourses." Public Policy and Administration 27 (2):99-119.

Teasdale, Simon, Fergus Lyon, and Robert Baldock. 2013. "Playing with Numbers: A Methodological Critique of the Social Enterprise Growth Myth." Journal of Social Entrepreneurship 4 (2):113-131.

Tedmanson, Deirdre, Karen Verduyn, Caroline Essers, and William B Gartner. 2012. "Critical Perspectives in Entrepreneurship Research." Organization 19 (5):531-541.

Van Maanen, John. 2011. Tales of the Field: On Writing Ethnography. Chicago: University of Chicago Press.

Watson, Tony J. 2011. "Ethnography, Reality, and Truth: The Vital Need for Studies of 'How Things Work'in Organizations and Management." Journal of Management Studies 48 (1):202-217. 
Wheeler, Peter. 2017. "Where Have All the Radicals Gone? How Normative Pressures Can Blunt the Radical Edge of a Social Enterprise." Social Enterprise Journal 13 (2).

Zasada, Magdalena. 2017. "Entrepreneurial Activity in Community Health Promotion

Organisations: Findings from an Ethnographic Study." Social Enterprise Journal 13 (2). 